\title{
Financialisation and the Portuguese private consumption: two contradictory effects?"
}

\author{
Financeirização e o consumo privado \\ português: dois efeitos contraditórios?
}

ANDREIA GONÇALVES**

RICARDO BARRADAS***

RESUMO: Este artigo faz uma avaliação empírica da relação entre a financeirização e o consumo privado português, realizando uma análise econométrica de séries temporais, do primeiro trimestre de 1996 ao terceiro trimestre de 2019. Emoldurada na literatura pós-keynesiana, a financeirização tem dois efeitos contraditórios sobre o consumo privado. $\mathrm{O}$ primeiro corresponde à queda do rendimento do trabalho das famílias, o que favorece uma desaceleração do consumo privado. O segundo corresponde ao aumento da dívida das famílias e ao aumento da riqueza financeira e habitacional das famílias, o que favorece uma aceleração do consumo privado. O efeito líquido global da financeirização tende a ser positivo porque o efeito benéfico da riqueza suprime o efeito prejudicial do rendimento. Estimamos uma equação de consumo privado que inclui quatro variáveis de controle (taxa de desemprego, taxa de inflação, taxa de juros de curto prazo e taxa de juros de longo prazo) e três variáveis ligadas à financeirização (rendimento do trabalho, riqueza financeira líquida e riqueza habitacional). Os nossos resultados confirmam que o rendimento do trabalho, a riqueza financeira líquida e a riqueza habitacional são determinantes positivos do consumo privado português. Os nossos resultados mostram também que a financeirização representou um importante motor do consumo privado português, principalmente devido aos efeitos benéficos da riqueza financeira líquida.

PALAVRAS-CHAVE: Consumo privado; financeirização; rendimento do trabalho; riqueza financeira líquida; riqueza habitacional; Portugal; modelo ARDL.

\footnotetext{
* The authors thank the helpful comments and suggestions of an anonymous referee, Sandro Mendonça, Sérgio Lagoa and the participants in ISCAL Research Seminar Series (Instituto Superior de Contabilidade e Administração de Lisboa, October 2019). The usual disclaimer applies.

* Iscte - Instituto Universitário de Lisboa, Lisboa, Portugal. Informa D\&B, Lisboa, Portugal. E-mail: andreia_goncalves@iscte-iul.pt. Orcid: https://orcid.org/0000-0002-5848-2415.

*** Iscte - Instituto Universitário de Lisboa, Dinâmia'CET-Iscte, Lisboa, Portugal. ISCAL - Instituto Superior de Contabilidade e Administração de Lisboa, Instituto Politécnico de Lisboa, Lisboa, Portugal. E-mail: ricardo_barradas@iscte-iul.pt. Orcid: https://orcid.org/0000-0003-0212-3568. Submitted: 8/ October/2018; Approved: 13/April/2020.
} 
ABSTRACT: This paper makes an empirical evaluation of the relationship between financialisation and the Portuguese private consumption by performing a time series econometric analysis from the first quarter of 1996 to the third quarter of 2019. Framed within the post-Keynesian literature, financialisation has two contradictory effects on private consumption. The first one corresponds to the fall in the households' labour income, which favours a deceleration of private consumption. The second one corresponds to the increase of households' debt and the increase of households' financial and housing wealth, which favours an acceleration of private consumption. The global net effect of financialisation tends to be positive because the beneficial wealth effect suppresses the harmful income effect. We estimated a private consumption equation that includes four control variables (unemployment rate, inflation rate, short-term interest rate and long-term interest rate) and three variables linked to financialisation (labour income, net financial wealth and housing wealth). Our results confirm that labour income, net financial wealth and housing wealth are positive determinants of Portuguese private consumption. Our results also show that financialisation has represented an important driver of Portuguese private consumption, particularly due to the beneficial effects of net financial wealth.

KEYWORDS: Private consumption; financialisation; labour income; net financial wealth; housing wealth, Portugal, ARDL model.

JEL Classification: C22; D10; E21; E44.

\section{INTRODUCTION}

During the last several years, finance has acquired great prominence and assumed growing dominance over the economy and society in the majority of countries. This phenomenon, commonly referred to as financialisation, has influenced the behaviour of economic agents, including households. In fact, the majority of households have increased their involvement in the realm of finance either as debtors and/or financial assets holders (Stockhammer, 2010; Lapavitsas, 2011; Van der Zwan, 2014; Barradas, 2016), which should have had an important effect on the evolution of total private consumption.

Effectively and following the post-Keynesian literature, scholars on financialisation have argued that this phenomenon has generated two contradictory effects on private consumption (Stockhammer, 2009a; Onaran et al., 2011; Hein, 2012). On the one hand, financialisation has led to a decrease of private consumption due to the decline of households' labour income. On the other hand, financialisation has led to an increase of private consumption due to the rise of both households' debt and households' financial and housing wealth. These authors also highlight that the global net effect of financialisation on private consumption has been positive because the supportive wealth effect has been sufficient to compensate the disruptive income effect.

From an empirical point of view, this issue has been assessed by several empirical studies that build and estimate private consumption equations by relating it with labour income and financial and housing wealth following the permanent in- 
come theory and life-cycle theory of consumption (Friedmand, 1957; Modigliani and Brumberg, 1954; Ando and Modigliani, 1963). Most of them conclude that labour income, financial wealth and housing wealth are positive determinants of private consumption (Boone et al., 1998; Ludvigson and Steindel, 1999; Davis and Palumbo, 2001; Edison and Sløk, 2001; Mehra, 2001; Boone and Girouard, 2002; Ludwig and Sløk, 2002; Castro, 2007; Farinha, 2008; Sousa, 2008, 2009; Slacalek, 2009; Onaran et al., 2011; Barrel et al., 2015; Barradas, 2017).

This paper aims to assess the role of financialisation in the evolution of Portuguese private consumption by performing a time series econometric analysis for the period of the first quarter of 1996 to the third quarter of 2019. This paper offers five important novelties to the existing literature. Firstly, the analysis is carried out specifically for Portugal. In fact, the evidence for Portugal is quite rather limited, situated in a context where the majority of empirical studies around this matter focus on highly developed and financialised countries, like the USA (Stockhammer, 2009a; Edison and Sløk, 2001). Portugal is an interesting case study, namely because its growth model in the last several years was essentially supported by the growth of private consumption by following a 'debt-led domestic demand' boom (Barradas et al., 2018), which occurred simultaneously with a general decreasing trend of labour income (Barradas and Lagoa, 2017). Secondly, the analysis covers the period where financialisation becomes more preponderant in Portugal (Barradas et al., 2018). Note that the majority of empirical studies includes a period where financialisation was not so much expressive - even in the USA - taking into account the general recognition that it emerges in the 1970s or 1980s (Kus, 2012; Sawyer, 2013; Vercelli, 2013; Tomaskovic-Devey et al., 2015). Thirdly, the analysis covers the period before, during and after the crisis, whilst the existing literature typically focuses on the period before the crisis. Barrel et al., (2015) and Barradas (2017) are the only exceptions, but their analyses are only centered on the United Kingdom and Italy and on the European Union countries as a whole, respectively. Fourthly, the analysis is carried out not only for the total private consumption or the private consumption of non-durable goods and services, which are the traditional strategies, but also for the private consumption of durable goods. Non-durable and durable private consumption tend to reflect different levels of satisfaction of needs by households, which implies that they can be affected differentially by labour income and (net financial and housing) wealth. Fifthly, the analysis also incorporates other important variables in the explanation of private consumption beyond labour income and net financial and housing wealth (Church et al., 1994; Boone et al., 1998; Davis and Palumbo, 2001; Boone and Girouard, 2002), which mitigates the problem of omitted relevant variables that could create inconsistent and biased estimates (Wooldridge, 2003; Kutner et al., 2005; Brooks, 2009). We recognise that Castro (2007) and Farinha (2008) also analyse this issue for Portugal, but they follow different strategies. The latter uses microdata at households' level and focuses its analysis only in 1994, 2000 and 2006. The former uses macrodata but its sample does not cover the period where financialisation became more common in Portugal; it also does not cover the recent period of crisis. Moreover, 
Castro (2007) only estimates the effects of labour income and wealth on private consumption of non-durable goods and neglects other important determinants of private consumption.

Against this backdrop, we modeled and estimated a private consumption equation by incorporating four control variables (unemployment rate, inflation rate, short-term interest rate and long-term interest rate) and three variables linked to the aforementioned contradictory effects of financialisation on private consumption (labour income, net financial wealth and housing wealth). Estimates are obtained using the Autoregressive Distributed Lag (ARDL) estimator due to existence of a mixture of variables that are integrated of order zero and one.

This paper concludes that labour income, net financial wealth and housing wealth are statistically significant, exerting a positive influence on the Portuguese private consumption. This paper also concludes that financialisation represents an important driver of Portuguese private consumption, particularly due to the beneficial effects of net financial wealth.

This paper is organised as follows. Second section presents a literature review on the effects of financialisation on private consumption. In third section, we build a private consumption equation and present expected theoretical effects of each variable on private consumption. Data and methodology are described in the fourth section. Empirical results are discussed in fifth section. Finally, the last section concludes.

\section{LITERATURE REVIEW}

Since the mid-1980s, finance has become larger in the majority of economies, dominating the real economy and society in general. This phenomenon, typically called as financialisation, has altered the behaviour of economic agents in their relationship into the realm of financial markets (Stockhammer, 2010; Lapavitsas, 2011; Barradas, 2016). Households have become more financially engaged, not only as debtors (particularly through credit), but also as holders of financial assets, which is also valid for the low-income and middle-class ones (Van der Zwan, 2014).

It seems clear, therefore, that financialisation has had an important effect on private consumption over the last several years. Effectively, and according to the post-Keynesian literature, the phenomenon of financialisation has been exerting two contradictory effects on private consumption (Stockhammer, 2009a; Onaran et al., 2011; Hein, 2012).

The first effect corresponds to a decline of the labour income, which tends to exert a negative effect on private consumption. Technological progress and globalisation are the traditional explanations referred in the literature to justify the fall of the labour income in the last years (European Commission, 2007; Stockhammer, 2009b; Guerriero and Sen, 2012; Dünhaupt, 2013a). Nonetheless, financialisation has also been referred to as an important driver of the fall of labour income (Hein, 2012; Hein and Detzer, 2014; Michell, 2014; Hein and Dodig, 2015), 
namely due to three main factors. The first is the alteration of the sectorial composition of economies, namely through the growing importance of the financial sector and the reduction of the weight of the general government. The second is the proliferation of 'shareholder value orientation' as a dominating model of corporate governance. The third is the erosion of trade unions with effects in the collective bargaining power of general workers. From an empirical point of view, the detrimental impact of financialisation on labour income has been widely supported (Stockhammer, 2009b, and 2017; Kristal, 2010; Peralta and Escalonilla, 2011; Dünhaupt, 2013b; Lin and Tomaskovic-Devey, 2013; Alvarez, 2015; Barradas and Lagoa, 2017; and Barradas, 2019).

The second effect corresponds to a rise in both debt and financial and housing wealth, which tends to exert a positive effect on private consumption. Several reasons are identified in the literature to explain the rise of wealth in recent years, namely a greater availability of credit supported by financial innovation and engineering related to debt securitisation and 'originate to distribute' operations (Hein, 2012); an economic situation characterised by historically low interest rates, which has deteriorated creditworthiness standards and has made credit (e.g., mortgages credit, consumer credit, credit cards and overdraft bank accounts) more available, even for low-income and low-wealth households (Hein, 2012); the adoption of more aggressive banking policies in the credit segment (Stockhammer, 2009a) mainly in an environment of increasing competition among banks (Boone and Girouard, 2002); the emergence of new financial instruments, like home equity loans and the aforementioned credit cards; the existence of some stock market and housing price boom episodes (Hein, 2012); and the emergence of remuneration schemes that include incentive payments to employees in the form of stock options (Edison and Sløk, 2001).

Nevertheless, the combined effect of these two contradictory effects on private consumption has been positive because the increase of the debt and wealth has more than compensated for the decrease in labour income (Stockhammer, 2009a; Onaran et al., 2011; Hein, 2012). Effectively, financialisation has allowed households to contour the fall in their wages, feed conspicuous consumption and follow a consumption imitation of Veblen and other goods by 'keeping up with the Joneses' (Hein, 2012). This is normally referred to as the 'demonstration effect' or 'Duesenberry effect' (Duesenberry, 1949). This households' behaviour in the era of financialisation has supported higher levels of consumption, even in a context of lower income ('consumption without income' hypothesis), which is normally called a 'ratchet effect' (Duesenberry, 1949). This means that the decrease of labour income does not necessarily imply a decline in the private consumption because households aim to maintain their standard of living by hiding from the other households what that have they lost.

Income and wealth effects on private consumption have been widely empirically tested (Boone et al., 1998; Ludvigson and Steindel, 1999; Davis and Palumbo, 2001; Edison and Sløk, 2001; Mehra, 2001; Boone and Girouard, 2002; Ludwig and Sløk, 2002; Castro, 2007; Farinha, 2008; Sousa, 2008, 2009; Slacalek, 
2009; Onaran et al., 2011; Barrel et al., 2015; Barradas, 2017). The majority of these empirical studies estimate private consumption equations by including labour income and wealth as the main determinants of private consumption following the permanent income and life-cycle theories (Friedman, 1957; Modgliani and Brumberg, 1954; Ando and Modgliani, 1963). According to these theories, private consumption essentially depends on households' permanent income, i.e., the current and expected future labour income plus their stock of wealth. Note that the majority of these empirical studies finds a positive relationship between labour income, financial and housing wealth and private consumption.

This paper aims to make an empirical analysis of the relationship between financialisation and private consumption by performing a time series econometric analysis for the Portuguese economy over the period from the first quarter of 1996 to the third quarter of 2019 . This paper aims to contribute to the existing literature in five different ways, namely by analysing Portugal; incorporating the period where financialisation becomes more preponderant in Portugal; incorporating the pre-crisis, crisis and post-crisis periods, respectively; assessing the effects of financialisation not only in total private consumption but also in non-durable and durable private consumption; and by including other control variables in the private consumption equation.

\section{MODEL AND HYPOTHESES: A PRIVATE CONSUMPTION EQUATION}

Our econometric model estimates a private consumption equation by including seven independent variables. The first four independent variables are the ones that are normally associated with private consumption by functioning as control variables such as: unemployment rate, inflation rate, short-term interest rate and long-term interest rate. ${ }^{1}$ The last three independent variables are linked to the two contradictory effects of financialisation on private consumption: labour income, net financial wealth and housing wealth. ${ }^{2}$

Indeed, our long-term private consumption equation takes the following form:

$$
P C_{t}=\beta_{0}+\beta_{1} U R_{t}+\beta_{2} I R_{t}+\beta_{3} S I R_{t}+\beta_{4} L I R_{t}+\beta_{5} L I_{t}+\beta_{6} F W_{t}+\beta_{7} H W_{t}+\alpha_{t}
$$

where $t$ is the time period (quarters), $P C$ is the private consumption, $U R$ is the unemployment rate, $I R$ is the inflation rate, $S I R$ is the short-term interest rate, $L I R$

\footnotetext{
${ }^{1}$ We include the short-term and the long-term interest rates as determinants of private consumption because households have increased their involvement into the realm of finance in the era of financialisation either as debtors (particularly through credit for mortgage purposes, which is more linked with the long-term interest rate) and/or financial assets holders (which is more linked with the short-term interest rates given the more conservative stance of households in their financial applications).

${ }^{2}$ We use the net financial wealth, i.e., the difference between financial assets and financial liabilities, in order to take into account the rise of households' net worth in the era of financialisation.
} 
is the long-term interest rate, $L I$ is the labour income, $F W$ is the net financial wealth, $H W$ is the housing wealth and $\alpha_{t}$ is an independent and identically distributed (white noise) disturbance term with null average and constant variance (homoscedastic).

Regarding the influence of each independent variable on private consumption, the unemployment rate and the inflation rate are expected to exert a negative effect, whereas labour income and net financial wealth are expected to exert a positive effect. Short-term interest rate, long-term interest rate and housing wealth have an ambiguous effect on private consumption. Thus, the coefficients of these variables are expected to have the following signs:

$$
\beta_{1}<0, \beta_{2}<0, \beta_{3} \gtrless 0, \beta_{4} \gtrless \beta_{5}<0, \beta_{6}<0, \beta_{7} \gtrless 0
$$

The unemployment rate affects private consumption negatively because it tends to reflect the business cycle by functioning as a proxy for uncertainty on households' future income levels (Boone et al., 1998; Boone and Girouard, 2002). Malley and Moutos (1996) highlight that the unemployment rate is a good proxy of uncertainty stressing that an increase of unemployment rate implies an increase of uncertainty, which boosts savings and dissuades private consumption in a precautionary context.

The inflation rate is also expected to exert a negative effect on private consumption because it is also used as proxy of uncertainty and of real depreciation of non-indexed financial assets (Boone et al., 1998; Boone and Girouard, 2002).

The effect of the short-term and the long-term interest rates on private consumption is ambiguous. This happens due to both income effect and substitution effect between private consumption and saving decisions by households. The income effect states that an increase in the level of interest rates generates a rise in income received by households' savings, which may lead to a higher level of private consumption due to the thought that they do not need to save as much to maintain their savings level. However, an increase in the level of interest rates also could dissuade private consumption because the returns of savings are now higher, which become more attractive, causing households to save more and spend less.

The labour income positively affects private consumption in line with the Keynesian theory (Keynes, 1936). Thus and following the absolute income theory of Keynes (1936), an increase in labour income implies an increase of private consumption but not by as much as the increase in labour income.

Private consumption is positively affected by financial wealth through five different channels (Ludwig and Sløk, 2002). The first channel is the 'realised wealth effect', which means that an increase in the value of financial assets boosts private consumption if households decide to liquidate these financial assets by obtaining the respective gains (Boone and Girouard, 2002). The second channel is the 'unrealised wealth effect', according to which an increase in the value of financial assets boosts private consumption because households feel more confident. Households expect that this trend will be maintained in the future, so they spend more now due to their expectations that their income and wealth will be higher when they decide 
to liquidate their financial assets and obtain the respective gains. The third channel is the 'liquidity constraint effect', which implies that an increase in the value of financial assets creates a rise in the value of households' portfolios, which tends to raise collateral values by allowing more borrowing leverage to finance private consumption. This is the so-called financial accelerator theory developed by Bernanke et al., (1996). The fourth channel refers to the 'stock option value effect', in which the increase in the value of households' stock options spurs their consumption levels. Finally, the fifth channel states that private consumption will be higher even by households that do not participate in financial market activities because they are also affected by an increase in the value of financial assets (Romer, 1990). According to Romer (1990), this happens because the evolution of financial assets is a good predictor of uncertainty on households' future income levels.

The housing wealth has an ambiguous effect on private consumption depending on whether households are house owners or house renters (Ludwig and Sløk, 2002). If households are home owners, three channels explain a positive effect of housing wealth on private consumption. The first channel is also the 'realised wealth effect', according to which a rise in house prices boosts private consumption if households decide to refinance or sell the house. The second channel is the 'unrealised wealth effect', which means that an increase in house prices boosts private consumption because households feel more confident. Households expect that this trend will continue in the future, so they will spend more now due to their expectations that their income and wealth will be higher when they decide to sell their house in the future. The third channel is the 'liquidity constraints effect', which implies that an increase in house prices raises collateral values by allowing more borrowing to finance private consumption. If households are home renters, two channels explain a negative effect of housing wealth on private consumption. The first channel is the 'budget constraint effect', according to which a rise in house prices is detrimental for private consumption due to expected rise of rents. ${ }^{3}$ The second channel is the 'substitution effect', which means that a rise in house prices is prejudicial for private consumption because the response of households that are home renters but which are planning to buy a house to this surge in house prices is to buy a smaller house or to lower spending expenditures.

\section{DATA AND METHODOLOGY}

Quarterly data was collected from the first quarter of 1996 to the third quarter of 2019, which corresponds to the period and frequency for which data for all

\footnotetext{
${ }^{3}$ Please note that this 'budget constraint effect' could also explain a negative relationship between housing wealth and private consumption for home owners. This is explained by the expected rise of other housing services (e.g., fuel and power) following a surge in house prices (Boone and Girouard, 2002; Ludwig and Sløk, 2002).
} 
variables are available. Nonetheless, our sample covers the period when financialisation gained more influence in Portugal (Barradas et al., 2018).

Regarding the definition of each variable and the respective sources, private consumption is proxied by total final consumption expenditures of resident households (at current prices and in millions of euros) collected from the Portuguese National accounts, available at Instituto Nacional de Estatística. We also collected the final consumption expenditures of resident households of durable goods (at current prices and in millions of euros) and non-durable goods and services (at current prices and in millions of euros) to assess durable and non-durable private consumption, respectively.

The unemployment rate corresponds to the harmonized unemployment rate for all persons (seasonally adjusted). This variable was collected from FRED Economic Data, available at Federal Reserve Bank of St. Louis.

The proxy to inflation rate used here is the annual percent change (year-onyear) of the consumer price index, which was collected from the Bank of Portugal database.

Short-term and long-term interest rates are the corresponding real interest rates obtained from monetary and financial statistics at the OECD database.

We used the annual percent change (year-on-year) of net disposable income (at current prices and in millions of euros) divided by gross domestic product (at current prices and in millions of euros) to measure households' labour income. These variables were extracted from the Portuguese National accounts, available at Instituto Nacional de Estatística. We use the net disposable income as a proxy for households' labour income because the labour income share is not available since the first quarter of 1996. Nevertheless, these two variables are quite correlated and the net disposable income has been used as a proxy of households' labour income in the majority of empirical studies on income and wealth effects (Boone et al., 1998; Ludvigson and Steindel, 1999; Mehra, 2001; Boone and Girouard, 2002; Ludwig and Sløk, 2002; Sousa, 2009; Barrel et al., 2015).

The variable of net financial wealth is proxied by the net worth, i.e., the difference between financial assets (at current prices and in millions of euros) and financial liabilities (at current prices and in millions of euros) of households. Both variables were extracted from the Portuguese financial accounts, available at Bank of Portugal database.

Finally, the housing wealth corresponds to the annual percent change (yearon-year) of real housing price index (at 2010 constant prices) and it was extracted from the analytical house price indicators, available at the OCDE database. We recognise that this is not a stock housing wealth variable, but there is not available information about the non-financial assets owned by Portuguese households. This variable has been widely used as a proxy of housing wealth (Boone et al., 1998; 
Ludwig and Sløk, 2002), albeit it seems to better reflect the potential capital gains (or losses) with housing wealth. ${ }^{4}$

Note that variables of private consumption, durable consumption, non-durable consumption and net financial wealth were deflated using the consumer price index from the Bank of Portugal database. In addition, these variables are expressed in annual percent change (year-on-year) in order to avoid multicollinearity problems that would appear if these variables were used in ratios of the gross domestic product or in natural logarithms.

Plots of our variables are available in Figure A1 in the Appendix. The descriptive statistics of our variables and the correlation coefficients among them are available upon request. All of the correlation coefficients are lower than the traditional ceiling of 0.8 in absolute terms, which suggests that there is no multicollinearity among our variables (Studenmund, 2005). Note that the correlation coefficient between labour income and private consumption is negative and the correlation coefficients between net financial and housing wealth and private consumption are both positives. This seems to confirm that two contradictory effects of financialisation on private consumption also characterised the Portuguese economy from the beginning of 1996 to the third quarter of 2019.

Now and in order to choose the more accurate econometric methodology, we assess the presence of unit roots for each variable by applying the traditional augmented Dickey and Fuller (1979) (ADF) test and the Phillips and Perron (1998) (PP) test. ${ }^{5}$ These two tests allow us to assess the order of integration of each variable. At the traditional significance levels, private consumption, inflation rate, short-term interest rate, net financial wealth and housing wealth are stationary in levels, i.e., they are integrated of order zero, according to the results of both tests. Unemployment rate only become stationary in first differences, i.e they are integrated of order one, in accordance with the results of both tests. Long-term interest rate and labour income are stationary in first differences by the ADF test, but stationary in levels by the PP test. All in all, we have a mixture of variables that are integrated of order zero and one.

Under this circumstance, we will employ the ARDL estimator proposed by Pesaran (1997), Pesaran and Shin (1999) and Pesaran et al., (2001). This estimator has three different advantages that justify its suitability in this specific case (Harris and Sollis, 2003). Firstly, this estimator does not require that all variables have the same integration order. Secondly, this estimator is strongly efficient even cases of small and finite samples. Thirdly, this estimator produces unbiased and consistent estimates.

According to this model, the dependent variable is explained by the lagged val-

\footnotetext{
${ }^{4}$ Thenceforth and particularly in the fifth section, we refer to this variable not to assess the housing wealth by itself but to measure the potential capital gains with housing wealth and its effects on the Portuguese private consumption.

${ }^{5}$ Results available upon request.
} 
ues of itself as well as the lagged and contemporaneous values of the independent variables. This econometric methodology involves four steps. Firstly, we need to analyse the number of the lags to be include in our estimation according to the information criteria. Secondly, we assess if there a cointegration relationship between our variables using the bounds test procedure proposed by Pesaran et al., (2001). Thirdly, we examine if our econometric model suffers from any econometric problem by conducting a set of diagnostic tests (autocorrelation, functional form, normality, heteroscedasticity and stability). Fourthly, we present both long-term and short-term estimates for our private consumption equation.

\section{EMPIRICAL RESULTS}

This section contains our estimates for Portuguese private consumption. We present the estimates not only for the total private consumption but also for nondurable and durable private consumption. ${ }^{6}$ Our estimates will be produced taking into account four lags, for two different reasons. Firstly, this is the number of lags indicated for quarterly data (Pesaran et al., 2001). Secondly, this is in accordance with some information criteria, and more specifically with LR and AIC criteria. ${ }^{7}$

Then, we apply the bounds test procedure to conclude regarding the existence of cointegration among our variables. The computed F-statistics are above the upper bound critical values, which indicates that the null hypothesis of no cointegration can be rejected. We therefore confirm that our variables are cointegrated. ${ }^{8}$

Next we conducted four diagnostic tests. ${ }^{9}$ According to the Breusch-Godfrey serial correlation LM test, we cannot reject the null hypothesis of no serial correlation. Using the Ramsey's RESET test, we do not reject the null hypothesis of no misspecification, confirming that our models are well specified in their functional forms. The null hypothesis that residuals are normal and homoscedastic cannot be rejected by the Jarque-Bera test and the Breusch-Pagan-Godfrey test, respectively. We also perform the cumulative sum of recursive residuals (CUSUM) test and the cumulative sum of squares of recursive residuals (CUSUMSQ) test, concluding that our coefficients are stable and that there are no significant structural breaks in our sample. All of these tests confirm that our models do not suffer from any serious econo-

\footnotetext{
${ }^{6}$ Please note that the consumption of services is included in the non-durable private consumption. In addition, estimates for durable and non-durable private consumption can also be obtained using the ARDL estimator because neither of these two variables is integrated of order two. Effectively and according to the ADF test, durable private consumption is integrated of order zero and non-durable consumption is integrated of order one. Following the PP test, durable and non-durable private consumption are both integrated of order zero. Results available upon request.

${ }^{7}$ E-views software (9.5 version) was used to produce our results. Note that the software automatically defines the number of lags to be incorporated in each variable up to the defined limit of four.

${ }^{8}$ Results available upon request.

${ }^{9}$ Results available upon request.
} 
metric problem and therefore we can proceed with the presentation of our longterm estimates (Table 1) and short-term estimates (Table 2, Table 3 and Table 4).

Table 1: The long-term estimates of private consumption

\begin{tabular}{|c|c|c|c|}
\hline Variable & Total & Non-Durable & Durable \\
\hline \multirow{3}{*}{$\beta_{0}$} & 0.013 & $0.034 * *$ & -0.172 \\
\hline & $(0.014)$ & $(0.009)$ & $(0.111)$ \\
\hline & [0.916] & [3.926] & {$[-1.541]$} \\
\hline \multirow{3}{*}{$U R_{t}$} & 0.111 & -0.110 & $2.633 * * *$ \\
\hline & $(0.123)$ & $(0.075)$ & $(0.946)$ \\
\hline & [0.899] & [-1.453] & {$[2.784]$} \\
\hline \multirow{3}{*}{$I R_{t}$} & 0.264 & 0.083 & 1.754 \\
\hline & $(0.224)$ & $(0.133)$ & $(1.829)$ \\
\hline & [1.180] & [0.629] & [0.959] \\
\hline \multirow{3}{*}{$S I R_{t}$} & $0.887 * * *$ & $0.622 * * *$ & $3.945 * * *$ \\
\hline & $(0.155)$ & $(0.098)$ & $(0.975)$ \\
\hline & [5.717] & [6.358] & [4.046] \\
\hline \multirow{3}{*}{$L I R_{t}$} & $-0.762 * * *$ & $-0.491 * *$ & $-4.644 * * *$ \\
\hline & $(0.123)$ & $(0.073)$ & $(0.822)$ \\
\hline & [-6.185] & {$[-6.740]$} & {$[-5.650]$} \\
\hline \multirow{3}{*}{$L I_{t}$} & $0.732 * * *$ & $0.322 *$ & $5.257 * * *$ \\
\hline & $(0.269)$ & $(0.163)$ & $(1.315)$ \\
\hline & {$[2.716]$} & [1.978] & [3.998] \\
\hline \multirow{3}{*}{$F W_{t}$} & $0.234 * * *$ & $0.099 * * *$ & $1.793 * * *$ \\
\hline & $(0.056)$ & $(0.036)$ & $(0.346)$ \\
\hline & [4.210] & [2.740] & {$[5.180]$} \\
\hline \multirow{3}{*}{$H W_{t}$} & $0.206 * * *$ & $0.113 * * *$ & 0.561 \\
\hline & $(0.067)$ & $(0.042)$ & $(0.509)$ \\
\hline & [3.088] & [2.688] & [1.101] \\
\hline
\end{tabular}

Note: Standard errors in ( ), t-statistics in [ ], *** indicates statistical significance at $1 \%$ level, ** indicates statistical significance at $5 \%$ level and * indicates statistical significance at $10 \%$ level.

In the long-term and regarding total private consumption, all variables are statistically significant at the conventional significance levels with the exception of unemployment rate and inflation rate. All the other variables that are statistically significant have the expected signs, confirming the previous empirical findings that private consumption is positively affected by labour income, net financial wealth and housing wealth (Boone et al., 1998; Ludvigson and Steindel, 1999; Davis and Palumbo, 2001; Edison and Sløk, 2001; Mehra, 2001; Boone and Girouard, 2002; Ludwig and Sløk, 2002; Castro, 2007; Farinha, 2008; Sousa, 2008, 2009; Slacalek, 2009; Onaran et al., 2011; Barrel et al., 2015; Barradas, 2017). Our results are also in line with the absolute income theory of Keynes (1936) given that the coefficient of labour income is less than one. Interest rates present mixed results in a context where shortterm interest rates exert a positive effect on private consumption but long-term in- 
terest rates exert a negative one. The most counterintuitive effect pertains to shortterm interest rates, which positively influence private consumption, which can be explained by three different channels. Firstly, a rise of interest rates accelerates private consumption though the aforementioned income effect of savings on private consumption. Secondly, a rise of interest rates boosts private consumption as households see this increase as a period of economic growth that favours by itself an increase of consumption expenditures. Thirdly, a rise of interest rates exacerbates private consumption taking into account the fears that this trend could persist in the future making the credit more costly, so households anticipate their consumption expenditures. A positive effect of interest rates on private consumption was also finding by Boone et al., (1998) for Italy, by Boone and Girouard (2002) for France and by Barradas (2017) for the European Union countries as a whole.

With regard to non-durable private consumption, results do not change radically. Effectively, variables that are statistically significant in the case of total private consumption are exactly the same in the case of non-durable private consumption and they exert the same effects. This is not too surprising given that the non-durable private consumption represents around the majority of consumption expenditures by the Portuguese households in the last several years. ${ }^{10}$

Finally and with regard to durable private consumption, the results also do not show a strong change. The only exception pertains to unemployment rate, which becomes statistically significant by exerting an unexpected positive influence. This suggests that an increase in the unemployment rate implies an acceleration of durable private consumption, which can be attributed to the existence of unemployment benefits that function as automatic stabilisers, the utilisation of savings, and rising debt by households. This happens due to the aforementioned 'ratchet effect' (Duesenberry, 1949).

In the short-term, three important conclusions deserve our attention. Firstly, total private consumption is strongly persistent, which is also true for non-durable private consumption. This consumption inertia or sluggishness is a well-recognised empirical fact in the literature due to consumption habits, adjustment costs of changing consumption, unconsciousness and inattention of households (Sørensen and Whitta-Jacobsen, 2005; Sommer, 2007; Slacalek, 2009; Sousa, 2009; Barrel et al., 2015). Secondly, coefficients of the error correction terms are negatives, lie between 0 and -2 and are strongly significant. This confirms the stability of our models and their convergence to the long-term equilibrium. The magnitude of the respective coefficients implies that nearly $69.2 \%, 85.7 \%$ and $53.8 \%$ of any disequilibrium of the long-term are corrected within one-quarter. Thirdly, our models describe reasonably well the behaviour of the Portuguese private consumption given the high values of R-squared and Adjusted R-squared, respectively.

\footnotetext{
${ }^{10}$ According to Instituto Nacional de Estatística, the non-durable consumption represents around $90 \%$ of the total private consumption in Portugal. Moreover, the non-durable consumption has exhibited a slightly increasing importance in the last years due to the increase of consumption expenditures on several services (e.g., health and education) and the growing satisfaction of basic needs by the Portuguese households.
} 
Table 2: The short-term estimates of total private consumption

\begin{tabular}{c|c|c|c}
\hline Variable & Coefficient & Standard Error & T-Statistic \\
\hline$\Delta P C_{t-2}$ & $0.230^{* * *}$ & 0.072 & 3.187 \\
$\Delta P C_{t-3}$ & $0.282^{* * *}$ & 0.066 & 4.296 \\
$\Delta P C_{t-4}$ & $0.227^{* * *}$ & 0.066 & 3.428 \\
\hline$\Delta I R_{t-1}$ & $-0.279 *$ & 0.152 & -1.834 \\
\hline$\Delta L I R_{t-1}$ & -0.087 & 0.166 & -0.522 \\
\hline$\Delta L I_{t-1}$ & 0.056 & 0.073 & 0.769 \\
$\Delta L I_{t-2}$ & $-0.602 * * *$ & 0.087 & -6.943 \\
$\Delta L I_{t-3}$ & $-0.391 * * *$ & 0.097 & -4.037 \\
$\Delta L I_{t-4}$ & $0.164 *$ & 0.085 & -1.923 \\
\hline$\Delta H W_{t-1}$ & 0.024 & 0.064 & 0.370 \\
$\Delta H W_{t-2}$ & $-0.186^{* * *}$ & 0.059 & -3.137 \\
\hline ECT & $-0.692^{* * 1}$ & 0.062 & -11.110 \\
\hline \multicolumn{2}{r}{-squared $=0.698$} & Adjusted $R$-squared $=0.656$ \\
\hline
\end{tabular}

Note: $\Delta$ is the operator of the first differences, ${ }^{* * *}$ indicates statistical significance at $1 \%$ level, ${ }^{*}$ indicates statistical significance at $5 \%$ level and ${ }^{*}$ indicates statistical significance at $1 \%$ level.

Table 3: The short-term estimates of non-durable private consumption

\begin{tabular}{|c|c|c|c|}
\hline Variable & Coefficient & Standard Error & T-Statistic \\
\hline$\Delta \mathrm{NDC}_{t-2}$ & $0.327 * * *$ & 0.072 & 4.555 \\
\hline$\Delta \mathrm{NDC}_{t-3}$ & $0.397 * * *$ & 0.069 & 5.773 \\
\hline$\Delta \mathrm{NDC}_{t-4}$ & $0.305 * * *$ & 0.067 & 4.526 \\
\hline$\Delta I R_{t-1}$ & $-0.272 * *$ & 0.118 & -2.298 \\
\hline$\Delta L I R_{t-1}$ & -0.035 & 0.121 & -0.291 \\
\hline$\Delta L I_{t-1}$ & -0.045 & 0.053 & -0.847 \\
\hline$\Delta L I_{t-2}$ & $-0.378 * * *$ & 0.062 & -6.102 \\
\hline$\Delta L I_{t-3}$ & $-0.234 * * *$ & 0.070 & -3.362 \\
\hline$\Delta L I_{t-4}$ & $-0.130 * *$ & 0.062 & -2.094 \\
\hline$\Delta F W_{t-1}$ & 0.041 & 0.026 & 1.569 \\
\hline$\Delta H W_{t-1}$ & 0.020 & 0.046 & 0.427 \\
\hline$\Delta H W_{t-2}$ & $-0.102^{* * *}$ & 0.043 & -2.382 \\
\hline$E C T_{t-1}$ & $-0.857 * * *$ & 0.078 & -11.003 \\
\hline \multicolumn{2}{|c|}{$R$-Squared $=0.701$} & \multicolumn{2}{|c|}{ Adjusted $R$-squared $=0.655$} \\
\hline
\end{tabular}

Note: $\Delta$ is the operator of the first differences, ${ }^{* * *}$ indicates statistical significance at $1 \%$ level, ${ }^{*}$ indicates statistical significance at $5 \%$ level and ${ }^{*}$ indicates statistical significance at $1 \%$ level. 
Table 4: The short-term estimates of durable private consumption

\begin{tabular}{c|c|c|c}
\hline Variable & Coefficient & Standard Error & T-Statistic \\
\hline$\Delta I R_{t-1}$ & -0.524 & 0.820 & -0.639 \\
$\Delta I R_{t-2}$ & $1.771 * *$ & 0.844 & 2.097 \\
$\Delta I R_{t-3}$ & $2.477 * * *$ & 0.852 & 2.908 \\
\hline$\Delta S I R_{t-1}$ & 1.328 & 1.617 & 0.821 \\
$\Delta S I R_{t-2}$ & -0.007 & 1.868 & -0.004 \\
$\Delta S I R_{t-3}$ & $-4.167 * * *$ & 1.521 & -2.739 \\
\hline$\Delta L I_{t-1}$ & 0.583 & 0.369 & 1.581 \\
$\Delta L I_{t-2}$ & $-2.869 * * *$ & 0.423 & -6.777 \\
$\Delta L I_{t-3}$ & $-1.755^{* * *}$ & 0.414 & -4.240 \\
\hline$\Delta H W_{t-1}$ & -0.008 & 0.343 & -0.023 \\
$\Delta H W_{t-2}$ & $-0.761 * *$ & 0.347 & -2.195 \\
\hline ECT & $-0.538 * * *$ & 0.055 & -9.806 \\
\hline \multicolumn{2}{c|}{$R$-squared $=0.635$} & Adjusted R-squared $=0.585$ \\
\hline
\end{tabular}

Note: $\Delta$ is the operator of the first differences, ${ }^{* * *}$ indicates statistical significance at $1 \%$ level, ${ }^{*}$ indicates statistical significance at $5 \%$ level and ${ }^{*}$ indicates statistical significance at $1 \%$ level.

Finally, we present the economic significance of our statistically significant long-term estimates (McCloskey and Ziliak, 1996; Ziliak and McCloskey, 2004). This allows us to identify the main drivers and constrainers of the Portuguese private consumption since 1996 and assess the role of the two contradictory channels linked to financialisation during that time (Table 5). As the Great Recession hit the Portuguese economy in a quite severely way (Figure A1 in the Appendix), this analysis is carried out for pre-crisis, crisis and post-crisis periods respectively. The dating of different periods was performed given the evolution of total private consumption (Figure A1 in the Appendix). For all three periods, we use the same long-term coefficients, taking into account that we have already excluded the existence of significant structural breaks. For simplicity and taking into account that the determinants of total private consumption and both non-durable and durable private consumption are not so different, this analysis only relapses on total private consumption. 
Table 5: Economic significance of our long-term estimates for total private consumption

\begin{tabular}{|c|c|c|c|c|}
\hline Period & Variable & $\begin{array}{l}\text { Long-term } \\
\text { Coefficient }\end{array}$ & $\begin{array}{c}\text { Actual } \\
\text { Cumulative Change }\end{array}$ & $\begin{array}{l}\text { Economic } \\
\text { Effect }\end{array}$ \\
\hline \multirow{5}{*}{$\begin{array}{c}\text { Pre-Crisis } \\
\text { Period } \\
(1996-2008)\end{array}$} & $S I R_{t}$ & 0.887 & -0.484 & -0.429 \\
\hline & $L I R_{t}$ & -0.762 & -0.545 & 0.415 \\
\hline & $L I_{t}$ & 0.732 & -0.086 & -0.063 \\
\hline & $F W_{t}$ & 0.234 & 0.365 & 0.085 \\
\hline & $H W_{t}$ & 0.206 & -0.084 & -0.017 \\
\hline \multirow{5}{*}{$\begin{array}{l}\text { Crisis Period } \\
(2009-2013)\end{array}$} & $S I R_{t}$ & 0.887 & -0.880 & -0.781 \\
\hline & $L I R_{t}$ & -0.762 & 0.358 & -0.273 \\
\hline & $L I_{t}$ & 0.732 & 0.039 & 0.029 \\
\hline & $F W_{t}$ & 0.234 & 0.085 & 0.020 \\
\hline & $H W_{t}$ & 0.206 & -0.153 & -0.032 \\
\hline \multirow{5}{*}{$\begin{array}{c}\text { Post-Crisis } \\
\text { Period } \\
(2014-2019)\end{array}$} & $S I R_{t}$ & 0.887 & -2.344 & -2.079 \\
\hline & $L I R_{t}$ & -0.762 & -0.944 & 0.719 \\
\hline & $L I_{t}$ & 0.732 & -0.001 & -0.001 \\
\hline & $F W_{t}$ & 0.234 & 0.262 & 0.061 \\
\hline & $H W_{t}$ & 0.206 & 0.409 & 0.084 \\
\hline \multirow{5}{*}{$\begin{array}{l}\text { Full Period } \\
(1996-2019)\end{array}$} & $S I R_{t}$ & 0.887 & -1.049 & -0.930 \\
\hline & $L I R_{t}$ & -0.762 & -0.971 & 0.740 \\
\hline & $L I_{t}$ & 0.732 & -0.057 & -0.042 \\
\hline & $F W_{t}$ & 0.234 & 0.901 & 0.211 \\
\hline & $H W_{t}$ & 0.206 & 0.121 & 0.025 \\
\hline
\end{tabular}

Note: The actual cumulative change corresponds to the annual percent change (year-on-year) of the correspondent variable (in levels) during the respective period. The economic effect is the multiplication of the long-term coefficient by the actual cumulative change.

In the period until the crisis, we conclude that the long-term interest rates and net financial wealth were the main drivers of the total private consumption. In fact, a decrease of the long-term interest rates and an increase of net financial wealth favoured an acceleration of the total private consumption by around 41.5 and 8.5 percent, respectively. Labour income and housing wealth had a slightly negative effect, contributing to a drop in the private consumption by about 6.3 and 1.7 percent, respectively. Accordingly, the global net effect of financialisation on total private consumption was considerably positive in the pre-crisis period.

During the crisis, labour income and net financial wealth were the single drivers of the total private consumption. Effectively, total private consumption would have been lower by about 2.9 and 2.0 percent if there had not been a rise in labour income and net financial wealth, respectively. The remaining variables constrained the evolution of the total private consumption. The fall of the short-term interest 
rates and housing wealth and the rise of the long-term interest rates implied a deceleration of the total private consumption by around 78.1, 3.2 and 27.3 percent, respectively. Against this backdrop, the global net effect of financialisation on total private consumption was marginally positive during the crisis because the beneficial effect of the labour income and net financial wealth have compensated for the prejudicial effects of the housing wealth.

After the crisis, the effects of each variable on total private consumption are quite similar to the pre-crisis period. The only exception is related to housing wealth, which begins to also represent a driver of the total private consumption, like long-term interest rates and net financial wealth. During that time, financialisation had a positive effect on total private consumption due to wealth effects. In fact, total private consumption would have been lower by about 6.1 and 8.4 percent if had there not been a rise in net financial wealth and housing wealth, respectively.

Taking into account the full period, we conclude that long-term interest rates were the main driver of the total private consumption, whilst the short-term interest rates had the worst impact. All in all, interest rates favoured a deceleration of the total private consumption because the positive effect of long-term interest rates was clearly insufficient to counterbalance the deleterious effect caused by shortterm interest rates. However, financialisation boosted the total private consumption from 1996 to 2019. The increase of net financial wealth and housing wealth delineated an acceleration of total private consumption of around 21.1 and 2.5 percent, respectively, more than compensating for the harmful effect of the fall in the labour income, which only contributed to a deceleration of total private consumption by about 4.2 percent.

To sum up, we confirm that financialisation cannot be dissociated from the behaviour of the Portuguese private consumption in the last several years; instead it represents an important driver of its evolution, particularly in the pre-crisis and post-crisis periods.

\section{CONCLUSION}

This paper aimed to evaluate the relationship between financialisation and Portuguese private consumption by performing a time series econometric analysis from the first quarter of 1996 to the third quarter of 2019.

From a theoretical point of view and follow the permanent income and lifecycle theories, private consumption essentially depends on households' permanent income, i.e., the current and expected future labour income plus their stock of wealth (Friedman, 1957; Modgliani and Brumberg, 1954; Ando and Modgliani, 1963). Against this backdrop, the post-Keynesian literature stresses that financialisation exerts two contradictory effects on private consumption (Stockhammer, 2009a; Onaran et al., 2011; and Hein, 2012). A negative effect occurs, due to the fall of labour income, and a positive effect arises due to the rise of net financial and 
housing wealth. These authors also emphasise that the global net effect of financialisation tends to be positive because the harmful income effect is more than compensated for by the beneficial wealth effect.

Accordingly, we estimated a private consumption equation using four control variables (unemployment rate, inflation rate, short-term interest rate and long-term interest rate) and three variables linked to the aforementioned contradictory effects of financialisation (labour income, net financial wealth and housing wealth). We have a mixture of variables that are integrated of order zero and one, which implied the utilization of the ARDL estimator.

Our findings confirm that the Portuguese private consumption is strongly persistent and that labour income, net financial wealth and housing wealth are positive determinants of Portuguese private consumption, in accordance with other empirical studies around this issue (Boone et al., 1998; Ludvigson and Steindel, 1999; Davis and Palumbo, 2001; Edison and Sløk, 2001; Mehra, 2001; Boone and Girouard, 2002; Ludwig and Sløk, 2002; Sørensen and Whitta-Jacobsen, 2005; Castro, 2007; Farinha, 2008; Sousa, 2008, 2009; Slacalek, 2009; Onaran et al., 2011; Barrel et al., 2015; Barradas, 2017). Our findings also confirm that financialisation cannot be dissociated from the evolution of Portuguese private consumption in the last several years, albeit its effects differ slightly across time. In the pre-crisis period, financialisation spurred Portuguese private consumption because the positive effect of net financial wealth suppressed the negative effects of the labour income and housing wealth. During the crisis period, financialisation also boosted the Portuguese private consumption because the positive effects of the labour income and net financial wealth counterweighed the negative effect of housing wealth. After the crisis, financialisation again boosted again Portuguese private consumption, due to the beneficial effects of net financial wealth and housing wealth. Over the full period, financialisation contributed to an acceleration of the Portuguese private consumption, particularly due the rise of net financial wealth.

Further research on this topic should focus on the empirical assessment of the causes of the increase of households' financial and housing wealth in the last several years, as well as on the respective consequences related with that increase, namely at the level of households' indebtedness.

\section{REFERENCES}

Ando, A. and Modigliani, F. 1963. 'The "Life Cycle” Hypothesis of Saving: Aggregate Implications and Tests'. American Economic Review, 53 (1): 55-84.

Alvarez, I. 2015. 'Financialization, non-financial corporations and income inequality: the case of France'. Socio-Economic Review, 13 (3): 449-475.

Barradas, R. 2016. 'Evolution of the Financial Sector - Three Different Stages: Repression, Development and Financialisation'. In Gomes, O. and Martins, H. F. (eds.). 2016. Advances in Applied Business Research: the L.A.B.S. Initiative, New York: Nova Science Publishers.

Barradas, R. 2017. 'Drivers of Private Consumption in the Era of Financialisation: New Evidence for 
the European Union Countries. Working Paper n 2017/04, Dinâmia'CET-IUL, ISCTE - Instituto Universitário de Lisboa, Lisboa.

Barradas, R. 2019. 'Financialization and Neoliberalism and the Fall in the Labour Share: A Panel Data Econometric Analysis for the European Union Countries. Review of Radical Political Economy. 51 (3): 383-417.

Barradas, R. and Lagoa, S. 2017. 'Functional Income Distribution in Portugal: The Role of Financialisation and Other Related Determinants'. Society and Economy. 39 (2): 183-212.

Barradas, R.; Lagoa; S.; Leão, E.; and Mamede, R. P. 2018. 'Financialisation in the European Periphery and the Sovereign Debt Crisis: The Portuguese Case'. Journal of Economic Issues, 52 (4): 10581085.

Barrel, R.; Costantini, M. and Meco, I. 2015. 'Housing Wealth, financial wealth, and consumption: New Evidence for Italy and the UK'. International Review of Financial Analysis, 42: 316-323.

Bernanke, B., Gertler, M. and Gilchrist, S., 1996. 'The Financial Accelerator and the Flight to Quality'. The Review of Economics and Statistics, 78 (1), 1-15.

Boone, L.; Giorno, C.; and Richardson, P. 1998. 'Stock Market Fluctuations AND Consumption Behaviour: Some Recent Evidence'. OECD Economics Department Working Paper $N^{\circ}$ 208, Paris.

Boone, L. and Girouard, N. 2002. 'The Stock Market, The Housing Market and Consumer Behaviour'. OECD Economic Studies $N^{\circ} 35$, Paris.

Brooks, C. 2009. Introductory Econometrics for Finance. $2^{\text {nd }}$ Edition. New York: Cambridge University Press.

Castro, G. L. 2007. 'The Wealth Effect on Consumption in the Portuguese Economy'. Economic Bulletin Winter, Lisbon: Bank of Portugal.

Church, K. P.; Smith, P. N. and Wallis, K. F. 1995. 'Econometric Evaluation of Consumers' Expenditure Equations'. Oxford Review of Economic Policy, 10 (2): 71-85.

Davis, M. A. and Palumbo, M. G. 2001. 'A Primer on the Economics and Time Series Econometrics of Wealth Effects'. Finance and Economics Discussion Series Working Paper $N^{\circ}$ 09, Washington.

Dickey, D. A. and Fuller, W. A. 1979. 'Distribution of the Estimators for Autoregressive Time Series with a Unit Root'. Journal of the America Statistical Association. 74 (366): 427-431.

Duesenberry, J. S. 1949. 'Income, Saving and the Theory of Consumer Behaviour'. Cambridge: Harvard University Press.

Dünhaupt, P. 2013a. 'Determinants of Functional Income Distribution - Theory and Empirical Evidence'. Working Paper $N^{\circ} 18$, Global Labour University.

Dünhaupt, P. 2013b. 'The Effect of Financialisation on Labor's Share of Income'. Working Paper $N^{o}$ 17/2013, Berlin: Institute for International Political Economy.

Edison, H. and Sløk, T. 2001. 'Wealth Effects and the New Economy'. IMF Working Paper $N^{\circ} 77$, Washington.

European Commission 2007. Employment in Europe 2007. Brussels: Directorate-General for Employment, Social Affairs and Equal Opportunities.

Farinha, L. 2008. 'Wealth Effects on Consumption in Portugal: A Microeconometric Approach'. Financial Stability Report. Lisbon: Bank of Portugal.

Friedman, M. 1957. 'A Theory of the Consumption Function'. Princeton: Princeton University Press.

Guerriero, M. and Sen, K. 2012. 'What Determines the Share of Labour in National Income? A Cross-Country Analysis'. Discussion Paper $N^{\circ}$ 6643, Germany: The Institute for the Study of Labor.

Harris, R. and Sollis, R. 2003. Applied Time Series Modelling and Forecasting. West Sussex: Wiley.

Hein, E. 2012. 'The Macroeconomics of Finance-dominated Capitalism - and its Crisis'. Cheltenham: Edward Elgar Publishing Limited.

Hein, E. and Detzer, D. 2014. 'Finance - Dominated Capitalism and Income Distribution: A Kaleckian Perspective on The Case of Germany'. FESSUD Working Paper Series $N^{\circ} 62$, University of Leeds: FESSUD Project.

Hein, E. and Dodig, N. 2015. 'Finance-dominated capitalism, distribution, growth and crisis - long-run tendencies'. In Hein, E; Detzer, D. and Dodig, N. (eds.). The Demise of Finance-dominated Capi- 
talism: Explaining the Financial and Economic Crises, Cheltenham: Edward Elgar Publishing Limited.

Keynes, J. M. 1936. 'The General Theory of Employment, Interest and Money'. London: Macmillan.

Kristal, T. 2010. 'Good times, bad times. Postwar Labor's Share of National Income in Capitalist Democracies'. American Sociological Review, 75 (5): 729-763.

Kus, B. 2012. 'Financialisation and Income Inequality in OECD Nations: 1995-2007'. The Economic and Social Review, 43(4): 477-495.

Kutner, M. H.; Nachtsheim, C. J.; Neter, J.; and Li, W. 2004. 'Applied Linear Statistical Models'. $5^{\text {th }}$ Edition. New York: Irwin/McGraw-Hill.

Lapavitsas, C., 2011. 'Theorizing financialization'. Work, Employment and Society, 25 (4), 611-626.

Lin, K. and Tomaskovic-Devey, D. 2013. 'Financialisation and US Income Inequality, 1970 - 2008'. American Journal of Sociology, 118 (5): 1284-1329.

Ludvigson, S. and Steindel, C. 1999. 'How Important Is the Stock Market Effect on Consumption?'. Economic Policy Review, 1999 (July): 29-51.

Ludwig, A. and Sløk, T. 2002. 'The Impact of Changes in Stock Prices and House Prices on Consumption in OECD Countries'. IMF Working Paper $N^{\circ} 1$, Washington.

Malley, J. and Moutos, T. 1996. 'Unemployment and Consumption'. Oxford Economic Papers, 48 (4): 584-600.

McCloskey, D. N. and Ziliak, S. T. 1996. 'The Standard Error of Regressions'. Journal of Economic Literature, 34 (1): 97-114.

Mehra, Y. P. 2001. 'The Wealth Effect in Empirical Life-Cycle Aggregate Consumption Equations'. Economic Quarterly, 87 (2): 45-68.

Michell, J. 2014. 'Factors Generating and Transmitting The Financial Crisis: Functional Distribution of Income'. FESSUD Working Paper Series $N^{\circ}$ 41, University of Leeds: FESSUD Project.

Modigliani, F. and Brumberg, R. 1954. 'Utility Analysis and The Consumption Function: An Interpretation of Cross-Section Data'. In Kurihara, K. K. (ed.). Post Keynesian Economics, New Brunswick: Rutgers University Press.

Onaran, Ö.; Stockhammer, E.; and Grafl, L. 2011. 'Financialisation, income distribution and aggregate demand in the USA'. Cambridge Journal of Economics, 35 (1): 637-661.

Peralta, I. A. and Escalonilla, F. L. 2011. 'Financiarización, Acumulación de Capital y Crecimiento Salarial en la UE-15'. Investigación Económica, 70 (276): 125-162.

Pesaran, M. H. 1997. 'The Role of Economic Theory in Modelling the Long Run'. Economic Journal. 107 (1): 178-191.

Pesaran, M. H. and Shin, Y. 1999. 'An Autoregressive Distributed-Lag Modelling Approach to Cointegration Analysis'. In Strøm, S. (ed.): Econometrics and Economic Theory in The Twentieth Century: The Ragnar Frisch Centennial Symposium. Cambridge: Cambridge University Press.

Pesaran, M. H.; Shin, Y.; and Smith, R. J. 2001. 'Bounds Testing Approaches to The Analysis of Level Relationships'. Journal of Applied Econometrics. 16 (1): 289-326.

Phillips, P. C. B. and Perron, P. 1998. 'Testing for a Unit Root in Time Series Regression'. Biometrika. 75 (2): 335-346.

Romer, C. D. 1990. 'The Great Crash and the Onset of the Great Depression'. The Quarterly Journal of Economics, 105 (3): 597-624.

Sawyer, M. 2013. 'What Is Financialization?' International Journal of Political Economy, 42(4): 5-18.

Slacalek, J. 2009. 'What Drives Personal Consumption? The Role of Housing and Financial Wealth'. ECB Working Paper Series $N^{\circ} 1117$, Frankfurt am Main.

Sommer, M. 2007. 'Habit Formation and Aggregate Consumption Dynamics'. The B.E. Journal of Macroeconomics, 7 (1): 1-25.

Sørensen, P. B. and Whitta-Jacobsen, H. J. 2005. 'Introducing Advanced Macroeconomics: Growth \& Business Cycles'. Maidenhead: McGraw-Hill.

Sousa, R. M. 2008. 'Financial Wealth, Housing Wealth, and Consumption'. International Research Journal of Finance and Economics, 19: 167-191. 
Sousa, R. M. 2009. 'Wealth Effects on Consumption: Evidence from the Euro Area'. ECB Working Paper Series $N^{\circ} 1050$, Frankfurt am Main.

Stockhammer, E. 2009a. 'The finance-dominated accumulation regime, income distribution and the present crisis'. Papeles de Europa, 19 (2009): 58-81.

Stockhammer, E. 2009b. 'Determinants of Functional Income Distribution in OECD Countries'. IMK Studies, Düsseldorf: Macroeconomic Policy Institute IMK at Hans Boeckler Foundation.

Stockhammer, E. 2010. 'Financialization and the Global Economy'. Political Economy Research Institute Working Paper $\mathrm{N}^{\circ} 240$. University of Massachusetts Amherst.

Stockhammer, E. 2017. 'Determinants of the Wage Share: A Panel Data Analysis of Advanced and Developing Economies'. British Journal of Industrial Relations, 55 (1): 3-33.

Studenmund, A. H. 2005. Using Econometrics: A Practical Guide. $5^{\text {th }}$ Edition, Boston: Addison Wesley Pearson.

Tomaskovic-Devey, D.; Lin, K. and Meyers, N. 2015. 'Did financialization reduce economic growth?'. Socio-Economic Review, 13(3): 525-548.

Van der Zwan, N. 2014. 'Making sense of financialisation'. Socio-Economic Review, 12 (1): 99-129.

Vercelli, A. 2013. 'Financialization in a Long-Run Perspective'. International Journal of Political Economy, 42(4): 19-46.

Wooldridge, J. M. 2003. 'Introductory Econometrics: A Modern Approach'. $2^{\text {nd }}$ Edition. Ohio: Thomson South-Western.

Ziliak, S. T. and McCloskey, D. N. 2004. 'Size matters: the standard error of regressions in the American Economic Review'. The Journal of Socio-Economics, 33 (5): 527-54.

\section{APPENDIX}

Figure A1: Plots of our variables
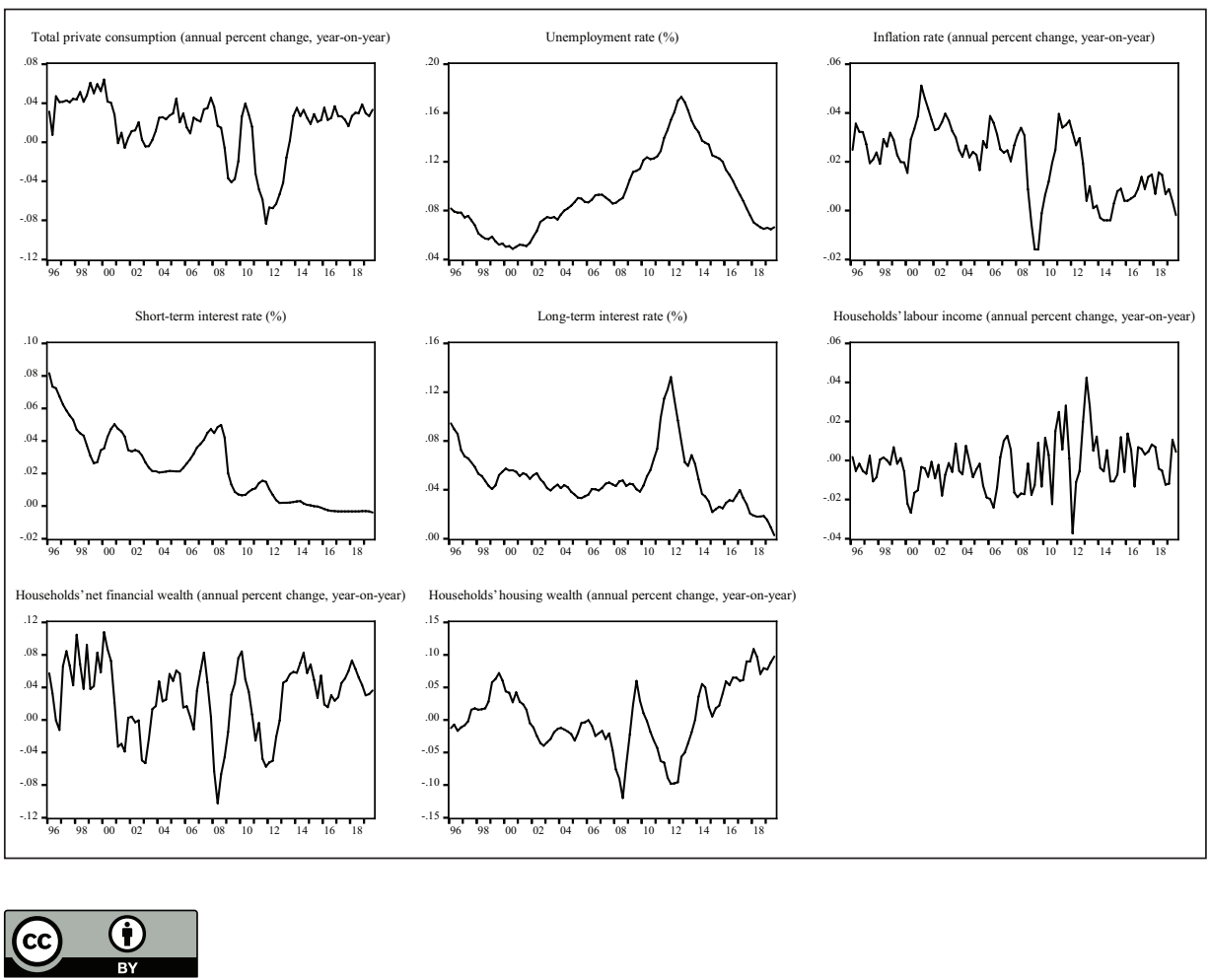